\title{
The effects of maternal haemoglobin as an indicator of maternal nutritional status on, maternal measles antibodies of mother-infant pairs at birth
}

\author{
*Baba UA ${ }^{1}$, Ashir $\mathrm{GM}^{2}$, Mava $\mathrm{Y}^{3}$, Gimba $\mathrm{MS}^{2}$, Abubakar R², Ambe JP2
}

1. Department of Paediatrics, Federal Medical Centre, Yola, Adamawa state, Nigeria; formerly, Department of Paediatrics University of Maiduguri Teaching Hospital (UMTH),Maiduguri, Borno state, Nigeria.

2. Department of Paediatrics, UMTH, Maiduguri, Borno state, Nigeria.

3. Department of Paediatrics, Bengham University, Jos, Plateau state Nigeria; formerly, Department of Paediatrics, UMTH, Maiduguri, Borno state, Nigeria.

\begin{abstract}
Background: Maternal measles antibodies (MMA) are actively transferred through the placenta from mother to foetus. A relationship could exist between MMA of mother-infant pairs and maternal nutritional indicator (haemoglobin). Objectives: This study reviewed the effects of maternal haemoglobin $(\mathrm{Hb})$ on MMA of mother-infant pairs at birth. Methods: One hundred and fifty three mother-infant pairs were enrolled in this study using the systematic random sampling method. Means of maternal $\mathrm{Hb}$ and MMA of mother-infant pairs were compared using the Student $\mathrm{t}$ test. Correlation coefficients of maternal $\mathrm{Hb}$ and MMA of mother-infant pairs were also determined. Multivariate analysis of variable (MANOVA) and covariates (MANCOVA) was used to investigate the effects of maternal $\mathrm{Hb}$ (fixed factor), gestational age, maternal age, birth weight (covariates) on combined MMA of mother-infant pairs (dependent factors). Benferroni adjusted Univariate linear regression was used to investigate the dependent variables separately.

Results: There were $78(51 \%)$ males and $75(49 \%)$ females. The (mean \pm SD) MMA of mother-infant pairs at birth were $134.66 \pm 93.31(95 \% \mathrm{CI}, 119.76-149.56) \mathrm{U} / \mathrm{ml}$, and $187.49 \pm 85.01(95 \% \mathrm{CI}, 173.91-201.07) \mathrm{U} / \mathrm{ml}$, and their correlation was significant $(\mathrm{p}=0.025)$. Ninety one $(59.5 \%)$ mothers had low Hb, $62(40.5 \%)$ had acceptable Hb levels. The overall mean maternal $\mathrm{Hb}$ was $11.01 \pm 1.00(95 \% \mathrm{CI}, 10.85-11.17) \mathrm{g} / \mathrm{dl}$. A positive significant correlation was observed between maternal $\mathrm{Hb}$ and MMA of the newborn-infant $(\mathrm{p}=0.031)$. The MANOVA showed a statistically significant difference between maternal $\mathrm{Hb}$ on the combined dependent variables ( $\mathrm{p}=0.033$ ); however, results for the dependent variables using the Benferroni adjusted Univariate analysis was significant for only MMA of the infants, $(p=0.009)$.

Conclusion: There was a significant association between aacceptable levels of maternal $\mathrm{Hb}$ and high MMA of the newborninfants. Therefore, these newborn infants start out with higher MMA that could give them better protection against measles during infancy.
\end{abstract}

Keywords: Maternal haemoglobin, maternal measles antibodies, Maiduguri, Nigeria. African Health Sciences 2013; 13(4): 940 - 946 http://dx.doi.org/10.4314/ahs.v13i4.12

\section{Introduction}

Measles is one of the most common communicable diseases and one of the major killers of infants in the world particularly in developing countries. Live attenuated measles vaccine is highly protective in preventing measles. ${ }^{1}$ Transplacental transfer of maternal measles antibodies (MMA) may protect

\section{*Corresponding author:}

Dr. Baba Usman Ahmadu

Department of Paediatrics

Federal Medical Centre Yola

Adamawa State, Nigeria

PMB 2017, Yola, Adamawa State, Nigeria.

Phone: +2348033668948

E-mail: ahmadu4u2003@yahoo.com infants against measles during infancy. ${ }^{2}$ Sadly, the transplacental transfer of MMA in mother-infant pairs is affected by numerous factors that may include poor nutrition. ${ }^{3}$ Measles is high in malnourished population most especially those found in tropical countries of the world. ${ }^{4,5}$ Possibly due to high prevalence of malnutrition associated with these countries. ${ }^{4,5}$ Low haemoglobin $(\mathrm{Hb})$ anaemia as an indicator of malnutrition causes diminished immune response to measles virus (MV), and this could lead to decreased levels of measles antibodies in a population. ${ }^{6}$

Poor nutrition and rapid loss of MMA in developing countries prompted suggestion for review of the existing immunization practices for 
measles. ${ }^{7}$ Malnutrition is one of the major public health problems and it is one of the leading cause of morbidity and mortality in Nigeria., 8 This may not be unconnected to high poverty rate existing in Nigeria. ${ }^{8}$ Different methods of estimating malnutrition in countries yielded high proportions of individuals with malnutrition. For instance, in Maiduguri, the prevalence of malnutrition was put at $36 \%$ using the modified Wellcome's classification. ${ }^{9}$ Other workers using the Gomez classification, however, documented $47 \%$ cases of malnutrition elsewhere. ${ }^{1}$ Estimation of $\mathrm{Hb}$ is a standard laboratory measure and good indicator that can give an idea about overall nutritional status of individuals in a community. ${ }^{10}$ Whereas the prevalence of malnutrition could vary from place to place, dearth of knowledge still exist world-wide on the extent to which maternal malnutrition affects MMA in mother-infant pairs particularly in our setting that is measles endemic.

Therefore, this work looked at the effects of maternal $\mathrm{Hb}$ as an indicator of maternal nutrition on MMA of mother-infant pairs at birth. To the best of our knowledge there is no study on this subject matter especially in North-Eastern Nigeria and the country at large.

\section{Methods}

\section{Study area}

The study was carried out at the Department of Paediatrics and Obstetrics unit of the University of Maiduguri Teaching Hospital (UMTH), Nigeria. The UMTH is a tertiary centre located in North-Eastern Nigeria and a centre of excellence for infectious diseases and immunology. It also serves as a referral site for the six North-Eastern States of Nigeria and the neighboring countries of Chad, Cameroon and Niger Republics.

\section{Study design}

The study was a hospital-based comparative cross sectional study of mother-infant pairs recruited from the labour ward of the UMTH.

\section{Ethical issues}

The study protocol was reviewed and authorised by the Medical Research and Ethics Committee of UMTH, and informed consent from parents was also obtained. Parents had unlimited liberty to deny consent without any consequences and confidentiality was maintained.

\section{Sample size/Subject selection}

The minimum sample size was determined using a statistical formula, which detects differences between two means when using paired sampling units: the effect size was set at 0.2 , alpha level at 0.05 and power at $90 \% .{ }^{11}$ However, $45 \%$ of the calculated minimum sample was added to maximize power. Therefore, the sample size for this study was one hundred and fifty-three mother-infant pairs. Consenting women who delivered vaginally at the UMTH were enrolled for this study. Severely sick pregnant women, those diagnosed with ante-partum haemorrhage, those delivering stillborns and mothers who had received blood transfusion during pregnancy were excluded.

\section{Data collection procedure}

Mother-infant pairs were enrolled in this study using the systematic random sampling method where the first of every three mother-infant pair was picked at the labour ward. Where the first mother did not fulfil the inclusion criteria, the immediate next mother that qualified was selected. On enrolment of the mother-infant pairs, study proforma were administered to the mothers to collect information on their bio-data, pregnancy history and antenatal care history. Dubowitz Score was used to access the gestational age (GA) of the newborn infants at birth, 12 and their birthweight (BW) was measured using the basinet weighing scale that has a sensitivity of 50 grams. Newborn infants with GA less than 37 completed weeks were classified as preterm, those from 37 completed to less than 42 completed weeks were term, and those with 42 completed weeks or more were post term. ${ }^{12,13}$ Newborns weighing > 3.99 kilograms were classified as macrosomia, those weighing $2.5-3.99$ kilogram as normal and those $<2.5$ kilogram were termed low BW.13

\section{Collection of Samples}

Three millilitres (mls) of venous blood were obtained from the mothers on admission using sterile disposable five mls syringe under aseptic technique. Of the three mls of maternal venous blood drawn, one $\mathrm{ml}$ was placed in ethylenediaminetetracetic acid (EDTA) bottle. This blood was used for the estimation of haemoglobin $(\mathrm{Hb})$ concentration in grams per decilitre $(\mathrm{g} / \mathrm{dl})$ using the microhaematocrit method. ${ }^{14}$ Low $\mathrm{Hb}$ is defined as $\mathrm{Hb}<$ $11 \mathrm{~g} / \mathrm{dl}$, while acceptable $\mathrm{Hb}$ is $\mathrm{Hb}>11 \mathrm{~g} / \mathrm{dl} .{ }^{15}$ The remaining two mls of maternal venous blood were placed in sterile plain bottles and serum was separated 
after centrifuging the blood samples at 5000 revolutions per minute (rpm) for five minutes. The sera obtained from maternal blood samples were used for the analysis of MMA using enzyme linked immunosorbent assay (ELISA).

Three millilitres of blood samples were also obtained from the umbilical cord of the newborn infants for the estimation of MMA. This was done after centrifuging the blood samples and the subsequent separation of the serum of the newborn cord blood. All blood samples collected were stored in a refrigerator at $-20^{\circ} \mathrm{C}$ until the time of MMA assay.

\section{Statistical analysis}

Statistical analyses were performed by use of SPSS statistical software version 16, Illinois, Chicago USA. Values were expressed as percentages, mean \pm standard deviation (SD) and range. Means of maternal $\mathrm{Hb}$ and MMA of mother-infant pairs were compared using the Student $t$ test. Correlation coefficients of maternal $\mathrm{Hb}$ and MMA of motherinfant pairs were also determined. Preliminary checks were conducted to ensure that there was no violation of the assumptions of normality, linearity, homogeneity of variances, homogeneity of regression slopes, and reliable measurement of the covariate. Multivariate analysis of variance
(MANOVA) and covariates (MANCOVA) was used to investigate the effects of maternal $\mathrm{Hb}$ (fixed factor), GA, MA, BW (covariates) on combined MMA of mother-infant pairs (dependent factors). Benferroni adjusted Univariate linear regression model was used to investigate the dependent variables separately. A p value $<0.05$ was considered significant. Tables were used appropriately for illustration.

\section{Results}

One hundred and fifty three mother-infant pairs were enrolled in this study. There were 78 (51\%) males and $75(49 \%)$ female newborn infants giving an approximate male to female ratio of 1.04:1. Thirteen (8.5\%), $138(90.2 \%)$ and $2(1.3 \%)$ newborn infants were preterm, term and postterm deliveries. Similarly, 17 (11.11\%), 130 (84.97) and 6 (3.92\%) newborn infants were low BW, normal and macrosomic deliveries. Table 1 shows the mean and range values of the study group. Maternal age ranges from 17 to 37 years, the mean MMA of motherinfant pairs was $134.66 \pm 93.31$ (95\% CI, $119.76-$ 149.56) $\mathrm{U} / \mathrm{ml}$ and $187.49 \pm 85.01$ (95\% CI, 173.91 - 201.07) $\mathrm{U} / \mathrm{ml}$ respectively in a ratio of $1: 1.3$. Correlation of these MMA was significant $(\mathrm{r}=0.182$, $\mathrm{p}=0.025)$ as shown in table 2 .

Table 1: Mean and range values of the study group

\begin{tabular}{lllc}
\hline Parameters & Mean \pm SD & 95\% CI & Range \\
\hline GA (weeks) & $38.78 \pm 1.83$ & $38.49-39.07$ & $30-43$ \\
MA (years) & $23.58 \pm 4.9$ & $22.78-24.38$ & $17-37$ \\
BW (Kg) & $3.06 \pm 0.57$ & $2.97-3.15$ & $1.25-4.60$ \\
MMA (U/ml) & $134.66 \pm 93.31$ & $119.76-149.56$ & - \\
MMA of Newborns $(\mathrm{U} / \mathrm{ml})$ & $187.49 \pm 85.01$ & $173.91-201.07$ & - \\
\hline
\end{tabular}

$\mathrm{SD}=$ Standard deviation, $\mathrm{CI}=$ Confidence interval, $\mathrm{GA}=$ Gestational age, $\mathrm{MA}=$ Maternal age, $\mathrm{BW}=$ Birth weight, MMA = Maternal measles antibodies

Table 2: Correlation of maternal haemoglobin and maternal measles antibodies of mother-infant pairs

\begin{tabular}{llcl}
\hline & $\begin{array}{l}\text { Maternal } \\
\text { Hb }(\mathrm{g} / \mathrm{dl})\end{array}$ & $\begin{array}{l}\text { Mothers MMA } \\
(\mathbf{U} / \mathbf{m l})\end{array}$ & $\begin{array}{l}\text { Newborns MMA } \\
(\mathbf{U} / \mathbf{m l})\end{array}$ \\
\hline Maternal Hb $(\mathrm{g} / \mathrm{dl})$ & $\mathrm{r}$ & 0.036 & 0.174 \\
& $\mathrm{p}$ & 0.658 & $0.031^{*}$ \\
Mothers MMA & $\mathrm{r}$ & & 0.182 \\
$(\mathrm{U} / \mathrm{ml})$ & $\mathrm{p}$ & & $0.025^{*}$ \\
Newborns MMA & $\mathrm{r}$ & & \\
$(\mathrm{U} / \mathrm{ml})$ & $\mathrm{p}$ & & \\
\hline
\end{tabular}

$\mathrm{Hb}=$ Haemoglobin $\mathrm{MMA}=$ Maternal measles antibodies $*=\mathrm{p}$ value $<0.05$ (significant) 
Of the $153(100 \%)$ mothers that participated in this study, 91 (59.5\%) were found to have low $\mathrm{Hb}$ (< $11 \mathrm{~g} / \mathrm{dl})$, and $62(40.5 \%)$ had acceptable Hb levels ( $>11 \mathrm{~g} / \mathrm{dl})$. The overall mean maternal $\mathrm{Hb}$ was 11.01 \pm 1.00 (95\% CI, 10.85 - 11.17) g/dl. Table 3 shows the comparison between maternal $\mathrm{Hb}$ and mean MMA of mother-infant pairs. The mean MMA of motherinfant pairs were higher for mothers who had acceptable $\mathrm{Hb}$ and low for mothers having low $\mathrm{Hb}$. However, the differences in mean MMA was only significant in newborn infants of mothers with acceptable $\mathrm{Hb}$ and low $\mathrm{Hb}(\mathrm{p}=0.002)$.

A positive correlation also existed between maternal $\mathrm{Hb}$ and MMA of mother-infant pairs. However, this correlation was only significant for maternal $\mathrm{Hb}$ and MMA of the newborn infants ( $\mathrm{r}=$ $0.174, \mathrm{p}=0.031$ ) table 2 .

Table 4 shows a statistically significant difference between maternal $\mathrm{Hb}$ on the combined dependent variables: $\mathrm{F}=3.490, \mathrm{p}=0.033$; Wilks' Lambda $=0.955$; partial eta squared $=0.045$. No significant difference was observed between the covariates (GA, MA and BW) on combined dependent variables. When the results for the dependent variables were considered separately, the only difference to reach statistical significance using a Bonferroni adjusted alpha level of 0.04 , was the relationship between maternal $\mathrm{Hb}$ and MMA of the infants: $\mathrm{F}=7.027, \mathrm{p}$ $=0.009$, partial eta squared $=0.045$ (table 5). No significant difference was observed between the covariates and the dependent variables separately.

Table 3: Comparison between maternal haemoglobin and mean maternal measles antibody of motherinfant pairs

\begin{tabular}{llcc}
\hline Maternal Hb (g/dl) & \multicolumn{2}{l}{ Mean maternal measles antibodies \pm SD $(\mathrm{U} / \mathbf{m l})$} \\
\cline { 2 - 4 } & Mothers & Newborn infants & p value \\
\hline $\begin{array}{l}\text { Acceptable } \mathrm{Hb}(\mathrm{g} / \mathrm{dl}) \\
(\mathrm{Hb}>11 \mathrm{~g} / \mathrm{dl})\end{array}$ & $127.21 \pm 63.38$ & $227.40 \pm 29.98$ & $0.000^{*}$ \\
$\mathrm{Low} \mathrm{Hb}(\mathrm{g} / \mathrm{dl})$ & $117.32 \pm 59.19$ & $175.98 \pm 53.29$ & $0.005^{*}$ \\
$(\mathrm{Hb}<11 \mathrm{~g} / \mathrm{dl})$ & & & \\
$\mathrm{p}$ value & 0.651 & $0.002^{*}$ & \\
$\mathrm{Hb}=$ Haemoglobin & $*=\mathrm{p}$ value $<0.05$ (significant) &
\end{tabular}

Table 4: Multiple tests of effect of maternal haemoglobin, maternal age, gestational age, birth weight on maternal measles antibodies of mother-infant pairs at birth

\begin{tabular}{|c|c|c|c|c|c|c|c|}
\hline Effect & & Value & $\mathbf{F}$ & $\begin{array}{l}\text { Hypo- } \\
\text { thesis df }\end{array}$ & Error df & $\begin{array}{l}\text { Sig. } \\
\text { Squared }\end{array}$ & Partial Eta \\
\hline \multirow[t]{4}{*}{ Intercept } & Pillai's Trace & 0.010 & $0.737^{a}$ & 2.000 & 147.000 & 0.480 & 0.010 \\
\hline & Wilks' Lambda & 0.990 & $0.737^{\mathrm{a}}$ & 2.000 & 147.000 & 0.480 & 0.010 \\
\hline & Hotelling's Trace & 0.010 & $0.737^{\mathrm{a}}$ & 2.000 & 147.000 & 0.480 & 0.010 \\
\hline & Roy's Largest Root & 0.010 & $0.737^{\mathrm{a}}$ & 2.000 & 147.000 & 0.480 & 0.010 \\
\hline \multirow[t]{4}{*}{$\overline{\mathrm{MA}}$} & Pillai's Trace & 0.001 & $0.075^{\mathrm{a}}$ & 2.000 & 147.000 & 0.927 & 0.001 \\
\hline & Wilks' Lambda & 0.999 & $0.075^{\mathrm{a}}$ & 2.000 & 147.000 & 0.927 & 0.001 \\
\hline & Hotelling's Trace & 0.001 & $0.075^{\mathrm{a}}$ & 2.000 & 147.000 & 0.927 & 0.001 \\
\hline & Roy's Largest Root & 0.001 & $0.075^{\mathrm{a}}$ & 2.000 & 147.000 & 0.927 & 0.001 \\
\hline \multirow[t]{4}{*}{$\overline{G A}$} & Pillai's Trace & 0.008 & $0.584^{\mathrm{a}}$ & 2.000 & 147.000 & 0.559 & 0.008 \\
\hline & Wilks' Lambda & 0.992 & $0.584^{\mathrm{a}}$ & 2.000 & 147.000 & 0.559 & 0.008 \\
\hline & Hotelling's Trace & 0.008 & $0.584^{\mathrm{a}}$ & 2.000 & 147.000 & 0.559 & 0.008 \\
\hline & Roy's Largest Root & 0.008 & $0.584^{\mathrm{a}}$ & 2.000 & 147.000 & 0.559 & 0.008 \\
\hline \multirow[t]{4}{*}{$\overline{\mathrm{BW}}$} & Pillai's Trace & 0.002 & $0.179^{a}$ & 2.000 & 147.000 & 0.836 & 0.002 \\
\hline & Wilks' Lambda & 0.998 & $0.179^{\mathrm{a}}$ & 2.000 & 147.000 & 0.836 & 0.002 \\
\hline & Hotelling's Trace & 0.002 & $0.179^{\mathrm{a}}$ & 2.000 & 147.000 & 0.836 & 0.002 \\
\hline & Roy's Largest Root & 0.002 & $0.179^{a}$ & 2.000 & 147.000 & 0.836 & 0.002 \\
\hline \multirow[t]{4}{*}{ Maternal Hb } & Pillai's Trace & 0.045 & $3.490^{\mathrm{a}}$ & 2.000 & 147.000 & $0.033^{*}$ & 0.045 \\
\hline & Wilks' Lambda & 0.955 & $3.490^{\mathrm{a}}$ & 2.000 & 147.000 & $0.033^{*}$ & 0.045 \\
\hline & Hotelling's 'Trace & 0.047 & $3.490^{\mathrm{a}}$ & 2.000 & 147.000 & $0.033 *$ & 0.045 \\
\hline & Roy's Largest Root & 0.047 & $3.490^{\mathrm{a}}$ & 2.000 & 147.000 & $0.033^{*}$ & 0.045 \\
\hline
\end{tabular}

a. Exact statistic Gestational age, b. Design: Intercept + MA + GA +BW + Maternal Hb

$\mathrm{MA}=$ Maternal age, $\mathrm{BW}=$ Birthweight, $\mathrm{Hb}=$ Haemoglobin $*=\mathrm{p}$ value $<0.05$ (significant) 
Table 5: Univariate tests of between-subjects effects

\begin{tabular}{|c|c|c|c|c|c|c|c|}
\hline Source & $\begin{array}{l}\text { Dependent } \\
\text { Variable }\end{array}$ & $\begin{array}{l}\text { Type III Sum } \\
\text { of squares }\end{array}$ & df & $\begin{array}{l}\text { Mean } \\
\text { square }\end{array}$ & $\mathbf{F}$ & Sig. & $\begin{array}{r}\text { Partial Eta } \\
\text { Squared }\end{array}$ \\
\hline \multirow[t]{2}{*}{ Corrected Model } & MMA & $14450.362^{\mathrm{a}}$ & 4 & 3612.591 & 0.408 & 0.802 & 0.011 \\
\hline & Newborn MMA & $52111.333^{b}$ & 4 & 13027.833 & 1.843 & 0.124 & 0.047 \\
\hline \multirow[t]{2}{*}{ Intercept } & MMA & 542.409 & 1 & 542.409 & 0.061 & 0.805 & 0.000 \\
\hline & Newborn MMA & 9007.171 & 1 & 9007.171 & 1.274 & 0.261 & 0.009 \\
\hline \multirow[t]{2}{*}{ MA } & MMA & 1151.523 & 1 & 1151.523 & 0.130 & 0.719 & 0.001 \\
\hline & Newborn MMA & 44.804 & 1 & 44.804 & 0.006 & 0.937 & 0.000 \\
\hline \multirow[t]{2}{*}{ GA } & MMA & 10339.637 & 1 & 10339.637 & 1.169 & 0.281 & 0.008 \\
\hline & Newborn MMA & 82.501 & 1 & 82.501 & 0.012 & 0.914 & 0.000 \\
\hline \multirow[t]{2}{*}{ BW } & MMA & 2099.622 & 1 & 2099.622 & 0.237 & 0.627 & 0.002 \\
\hline & Newborn MMA & 1323.611 & 1 & 1323.611 & 0.187 & 0.666 & 0.001 \\
\hline \multirow[t]{2}{*}{ Maternal $\mathrm{Hb}$} & MMA & 1727.031 & 1 & 1727.031 & 0.195 & 0.659 & 0.001 \\
\hline & Newborn MMA & 49681.788 & 1 & 49681.788 & 7.027 & $0.009 *$ & 0.045 \\
\hline \multirow[t]{2}{*}{ Error } & MMA & 1309085.964 & 148 & 8845.175 & & & \\
\hline & Newborn MMA & 1046450.902 & 148 & 7070.614 & & & \\
\hline \multirow[t]{2}{*}{ Total } & MMA & 4097939.000 & 153 & & & & \\
\hline & Newborn MA & 6476906.000 & 153 & & & & \\
\hline \multirow[t]{2}{*}{ Corrected Total } & MMA & 1323536.327 & 152 & & & & \\
\hline & Newborn MMA & 1098562.235 & 152 & & & & \\
\hline
\end{tabular}

a. $\mathrm{R}$ Squared $=.011$ (Adjusted R Squared $=-.016 \mathrm{~b}$. R Squared $=.047$ (Adjusted R Squared $=.022$ )

$*=\mathrm{p}$ value $<0.05$ significant, $\mathrm{Hb}=$ Haemoglobin, $\mathrm{GA}=$ Gestational age, $\mathrm{MA}=$ Maternal age

$\mathrm{BW}=$ Birth weight, $\mathrm{MMA}=$ Maternal measles antibodies

\section{Discussion}

Present study revealed a high MMA in mother-infant pairs at birth, with newborn infants having higher levels of MMA than their corresponding mothers. This is similar to the observations that were made in Lagos, Nigeria three decades ago and from other studies conducted in other parts of the world. ${ }^{1,16,17}$ Active placental transfer of MMA from mothers to their foetuses could be the likely explanation for the newborn infants having higher MMA than their mothers. ${ }^{18}$ The high levels of MMA that was found in the study population could be as a result of the boosting effect of MMA by MV, stemming from the fact that measles is endemic in our setting. ${ }^{7}, 17,18$

Whereas, acceptable maternal $\mathrm{Hb}$ yielded higher mean MMA, low maternal $\mathrm{Hb}$ was associated with low MMA of mother-infant pairs in this work. Maternal $\mathrm{Hb}$, in fact, was found to contribute significantly towards newborn-infants having much more MMA than their mothers. This conformed to the observation made by other authors' in both developed and resource poor countries of the world. ${ }^{17-19}$ The transfer of macromolecules from mother to their foetuses via the placenta in most cases is a reflection of maternal nutrition. The placenta exerting activating mode of action towards preferential concentration of some macromolecules in the foetus. ${ }^{19}$ In this regard, MMA being macromolecules would be better passed from mother to foetus where maternal $\mathrm{Hb}$ is acceptable relative to mothers with low $\mathrm{Hb}$ since maternal $\mathrm{Hb}$ is a good indicator of maternal nutrition. ${ }^{1}$

Apart from being a good indicator of mother's health and nutrition, maternal $\mathrm{Hb}$ also has a long-term health benefit in babies. This could include newborn infants starting out with high levels of MMA. ${ }^{1,17-18}$ The present study showed that infants of mal-nourished mothers (low $\mathrm{Hb}$ ) are more prone to measles. Reason being that, these newborn infants are delivered with lower MMA; these antibodies may not last long enough to protect them against measles during infancy. ${ }^{18}$ The low MMA in infants whose mothers have low $\mathrm{Hb}$ are further cleared by overwhelming and recurrent infections among other causes, thereby, making these children highly vulnerable to measles and its complication chief amongst them malnutrition. ${ }^{18,20}$ Growth faltering and developmental delay subsequently sets in in those who continue to be malnourished following measles in this vulnerable group. 
Even though the mean MMA of motherinfant pairs of cohorts having low maternal $\mathrm{Hb}$ was low compared to subjects whose mothers had high (acceptable) Hb, their mean MMA was, nonetheless, protective in present study. Similar finding was made by victor et al, ${ }^{18}$ in the year 2000 . Mothers that were found with low $\mathrm{Hb}$ in this study could still be producing measles antibodies probably from exposure to MV. Moreover, some workers have found that humoral immunity is not impaired even under acute nutritional stress. ${ }^{21}$ This means that, mothers with low $\mathrm{Hb}$ as seen in our study could respond to MV challenge by producing high levels of MMA, which are transferred to their babies.

Maternal age, GA and BW did not significantly affect MMA of mother-infant pairs in this work. Other workers had reported similar findings with respect to MA and BW, however, GA age was found to vary directly with MMA in motherinfant pairs. ${ }^{1,16-18}$ The possible explanation for our observation may be that most of the mothers are very young in their twenties, majority of the newborn infants are term and with normal BW. The transfer of MMA in mother-infant pair across the placenta occurs maximally from the third trimester of pregnancy that is from 28 weeks of gestation onward. 1, 16,17 The least GA in this study was 30 weeks and since the study was not primarily design to compare MA, GA and BW with MMA of mother-infant pairs, our finding in this regard is anticipated.

Most developing and sub-Saharan countries like Nigeria are saddled with malnutrition and high cases of measles. The scourge of measles and its complications, such as malnutrition in children from these poor nations could be reduced if mothers thought of health values like adequate nutrition. These would ensure acceptable $\mathrm{Hb}$ levels in mothers, which could in turn generate high levels MMA. Information obtained from this study may be of public health benefit because policy makers can use this work as a platform to improve on the existing maternal health practices geared towards improving maternal nutrition. By improving maternal nutrition, higher levels of MMA could be generated, which could prevent infants from measles.

\section{Conclusion}

Mothers with acceptable $\mathrm{Hb}$ gave birth to newborn infants with higher levels of MMA compared to the low levels of MMA observed in newborns whose mothers had low Hb. Thus, newborn infants of mothers with acceptable $\mathrm{Hb}$ in the current work have better protection against measles.

\section{Limitations}

This work was performed at the UMTH, which makes it a uni-centered study. This is a setback because caution is needed in generalizing the results of this research. Data on MA, GA and BW were skewed towards very young MA, term deliveries and normal BW. These could be another drawback because skewed distribution of data is a shift from normal population distribution that may interfere with the interpretation of results.

\section{Recommendations}

In order to eliminate measles in children in our setting, there is need for relevant authorities to re-strategize and implement maternal health practices like adequate nutrition. The girl child should be educated and be well informed on good nutritional habits. This will help in generating acceptable maternal $\mathrm{Hb}$ and high levels of MMA needed to protect infants against measles during the child bearing age of the girl child. Studies of this kind in the future should include mother-infant pairs from multiple health centers in order to have a representative cross-section of the study population. Furthermore, a study design that accommodates all MA groups within the child bearing age, GA groups and BW groups in greater frequencies is also recommended in order to improve the power of the relationship between these variables and MMA.

\section{Contributors}

BUA, AGM, MY, and AJP conceived and designed the study; all authors assessed and interpreted the data and wrote the draft of the report. All authors were involved in the critical revision of the paper.

\section{Acknowledgment}

We are grateful to Mallam Abdulmumini G, and Tahiru $\mathrm{H}$ for their help.

\section{References}

1. Kamar S, Chowdhury O, Murshed M, Hasan R. Effect of Gestational Age and Nutrition on Transplacental Transfer of Measles Antibody. Med Today 2010; 22:1-5.

2. Stitteiear KE, Barbosa V, Lima OS. Vaccination against measles; A never ending story. Review of vaccine 2002;1: 151-59. 
3. Scott S, Cumberland P, Shulman CE. Neonatal measles immunity in rural Kenya: the influence of HIV and placental malaria infections on placental transfer of antibodies and levels of antibody in maternal and cord serum samples. J Infect Dis 2005;191:1854-60

4. Bellini WJ, Icenogle JP. Measles and Rubella viruses. In:Murry PR, Baron EJ, Joreensen JH editors. Manual of clinical microbiology. 8th ed. Washigton DC. ASM press 2003;1389-94

5. Assaad F. Measles: Summary of worldwide impact. Reviews of infectious Diseases 1983;5: 452-59.

6. Whittle HC, Aaby P. Measles. In: Warrell AD, Cox DJ, Benz JE editors. Oxford textbook of medicine. $14^{\text {th }}$ ed. New York:Oxford University press 2003;375-81.

7. Sood DK, Kumar S, Singh S. Transplacental immunity \& wanning of maternal antibody in measles. Indian J Pediatrics 1996;62: 95-9.

8. World Health Organisation. Country health system fact sheet Nigeria 2006.

9. Hamidu JL, Salami HA, Ekanem AU, Hamman L. Prevalence of protein-energy malnutrition in Maiduguri, Nigeria. AfrJ Biomed Res 2003; 6: 12327.

10. Omran ML, Morley JE. Assessment of protein energy malnutrition in older persons, Part2: Laboratory Evaluation. Nutrition 2000; 16:13140.

11. Browner WS. Estimating sample size and power. In Hulley SB, Cummings SR, Grady D, Hearst N, Newman TB eds. Designing Clinical Research, $2^{\text {nd }}$ ed. Philadelphia: Lippincott Williams \& Wilkins, 2001. P. 65-84.

12. Dubowitz L, Dubowitz V, Goldberg C. Clinical assessment of gestational age in the newborn infant. Pediatrics 1970;77:1-10.
13. Uche N. Assessment and care of the newborn. In: Azubuike JC, Nkanginieme KE, editors. Pediatrics and Child Health in a Tropical Region. 2nd ed. Owerri: African Educational Services; 2007. p. 16377.

14. Barbara B. Performing a blood count. In: Maria K, Saskia V, Rob B editors. Blood Cells A Practical Guide. $4^{\text {th }}$ ed. Australia: Blackwell; 2006.p.31-7.

15. Ogunbode O. Anaemia in pregnancy. TJOG 1995; 12: 19-25.

16. Harry TO, Ogunmekan DA. Optimal age for vaccinating Nigerian Children against measles.I.Neonatal antibody profile and subsequent susceptibility to measles. Trop Geogr Med 1981; 33: 375-8.

17. Joshi RR, Gambhir PS. A Study of Measles antibody levels from birth till 9 months of age: Correlation with maternal titres and maternal nutrition Bombay Hosp J 2003; 45: 40-5.

18. Victor MC, Peter MS, Roland WS. Factors determining prevalence of maternal antibody to measles virus throughout infancy: A review. Clin Infect Dis 2000; 31:110-19.

19. Elizabeth KE, Viji K, Vijayakumar T. Umbilical cord blood nutrients in low birth weight babies in relation to birth weight $\&$ gestational age. Indian J Med Res 2008;128:128-33

20. Perry RT, Halsey NA. The Clinical Significance of Measles: A Review. J Infect Dis 2004; 189:1374-81.

21. Das MK, Das K. Immunoglobulin levels in populations with low hemoglobin levels: study of five tribes of central India. J Hum Biol 1995; 67: 933-42. 